\title{
LOS FEMINISMOS FRANCESES FRENTE AL RELEVO GENERACIONAL DEL NUEVO MILENIO: UN ACTIVISMO ENTRE RUPTURA Y CONTINUIDAD
}

\section{FRENCH FEMINISMS AND GENERATIONAL RENEWAL IN THE 2000S: RUPTURE OR CONTINUITY FOR ACTIVISTS?}

\author{
Karine Bergès \\ Universidad de Cergy-Pontoise (Francia) \\ orcid.org/0000-0002-2516-2538
}

Recibido el 28-6-2016 y aceptado el 12-9-2016

\begin{abstract}
Resumen: Esta investigación reflexiona en torno al relevo generacional en el seno del movimiento feminista francés a partir de los enfoques ideológicos, repertorios de actuación y formas de organización de colectivos jóvenes que vieron la luz en la década de los años 2000. Partiendo de las trayectorias de algunos grupos feministas de la tercera ola que reivindican tanto un feminismo moderado como un feminismo radical, examinaremos su identificación o falta de identificación con respecto al legado de las generaciones feministas anteriores y analizaremos cuáles son las herramientas a su alcance, en particular las nuevas tecnologías, para revitalizar las praxis feministas en la época contemporánea.
\end{abstract}

Palabras claves: feminismo, activismo, relevo generacional, tercera ola, nuevas tecnologías, Femen.

\begin{abstract}
This article reflects on the generational renewal within the French feminist movement. It will focus on its ideological postulates and core ideas, its ways of action and the new young and alternative movements which have emerged in the 2000s. Analysing the path of some of these groups representing a third wave of feminism - which claim to be coming from what is called «the feminism of influence» or «radical feminism» - the article focuses on the identification or (mis)identification of such groups to the feminism of previous generations and centres on the tools they use, such as those of new technologies, to refresh feminist practices nowadays.
\end{abstract}

Key words: Feminism, activism, generations, third wave, new technologies, Femen. 
El camino del feminismo consiste en la fidelidad a grandes principios, pero también en la capacidad de poner en cuestión incluso lo que considerábamos como ya resuelto. Es una acción plural y no una fabricación conforme a un modelo ${ }^{1}$.

Estas palabras de la filósofa feminista belga Françoise Collin, en su intento de definir la trayectoria y los legados del feminismo occidental, sirven de introducción para abrir una reflexión sobre las mutaciones del feminismo contemporáneo y su capacidad para renovarse más allá de la heterogeneidad de sus planteamientos y de las identidades que lo atraviesan. Reflejar estas transformaciones y dar cuenta del relevo generacional, al que asistimos al hilo de la época contemporánea, constituye el propósito central de este texto que no tiene la pretensión de ser una cartografía exhaustiva del «hacer y ser feminista» en la época actual, sino una reflexión limitada a algunos colectivos jóvenes representativos de las corrientes más visibles del feminismo contemporáneo en el panorama militante francés. Si desde el principio del nuevo milenio, Francia ha asistido a una eclosión del activismo feminista a cargo de una nueva generación de mujeres jóvenes con un alto compromiso militante, indagaremos en la formación y la posterior trayectoria de estos grupos identificados con «la tercera ola del feminismo» ${ }^{2}$ así como en los postulados ideológicos y las formas organizativas que están elaborando. Examinaremos en particular el uso que estos grupos hacen de las nuevas tecnologías de la información como herramientas políticas para movilizar y crear redes feministas capaces de coordinar estrategias de comunicaciones o difundir masivamente informaciones alternativas. Siguiendo las teorías de la filósofa italiana Rosi Braidotti ${ }^{3}$ o de la socióloga bri-

1 Collin, Kaufer, 2005, p. 19. De ahora en adelante, todas las traducciones al castellano de citas francesas o de fragmentos de las entrevistas realizadas en francés corren a cargo de la autora.

2 Retomamos aquí la definición del feminismo de tercera ola como «un feminismo que surge en este contexto de crisis, crece en medio de la maleza del impasse político y existencial que arrasa las certezas del presente y del futuro. Aparecen nuevas temáticas, se fragmentan los grupos, emergen otras prácticas, se expanden las diferencias, se cuestionan las identidades y se asiste al final del sujeto único», Gil, 2011, p. 35.

3 Rosi Braidotti, «Un ciberfeminismo diferente», 1996. <http://www.estudiosonline. net/texts/diferente.html>. [23/09/2013]. 
tánica Judy Wajcman ${ }^{4}$, pondremos de manifiesto cómo las feministas del siglo XXI han tenido que renunciar a la tecnofobia para enfrentarse a los desafíos de su tiempo, utilizando para su empoderamiento los instrumentos de la sociedad de información nacida de la globalización. A lo largo de este estudio, iremos cuestionando el advenimiento de «un nuevo feminismo» o de un «post-feminismo», y examinaremos en qué medida se puede afirmar que estos colectivos jóvenes navegan entre un deseo de auto-afirmación de su legitimidad, que apuesta por la renovación de sus teorías y praxis y, al mismo tiempo, una deuda hacia el legado de las generaciones históricas anteriores. En este sentido, se llevará a cabo un análisis crítico del activismo de los colectivos nacidos en Francia al calor de la década de los años 2000, que se reclaman integrantes de una nueva generación y dan cuenta de la (re)dinamización del feminismo.

A lo largo de las siguientes páginas, dedicaremos el primer apartado de este texto a asentar los fundamentos del llamado feminismo de la tercera ola y su traducción en el espacio feminista francés. A continuación, nos centraremos en la experiencia de unos colectivos de creación reciente, representativos de lo que María Martínez González pasó a denominar «un feminismo de denuncia», que «parte del sujeto-mujersujetado denunciando su situación de dominación bajo el patriarcado y buscando su liberación mediante el cambio de la estructura social ${ }^{5}$. El colectivo francés $O s e z$ le féminisme, fundado en 2009, y sus campañas de demanda de derechos y cambios de leyes, serán el objeto de esta reflexión. En el último capítulo, analizaremos otras formas de movilización radicalmente diferentes que encajan con lo que el sociólogo francés Eric Fassin definió como un «feminismo de subversión» ${ }^{6}$, radical, autónomo, provocativo, cuyo objetivo estriba en sacudir las conciencias de la sociedad con acciones transgresoras celebradas en el espacio público. El colectivo Femen, nacido en Ucrania al calor de la Revolución Naranja de 2008, y afincado en París desde el año 2012, centrará nuestra atención y permitirá formular algunas conclusiones y pistas de reflexión en torno al activismo globalizado.

\footnotetext{
4 Wajcman, 2006.

5 Martínez González, 2015, p. 217.

${ }^{6}$ Fassin, 2015 (Las traducciones al francés son nuestras).
} 


\section{El feminismo de tercera ola: breve repaso histórico}

Después del backlash ${ }^{7}$ de los años 80 y de la progresiva institucionalización del feminismo ${ }^{8}$ se hubo de esperar a la mitad de los años 90 para presenciar un relevo generacional en el seno del movimiento feminista. Desde entonces, el feminismo ha entrado en una nueva fase caracterizada por una proliferación de colectivos que no lo consideran como un reto autónomo sino que incluyen su militancia en el marco de un combate más transversal, cruzando el sexo, la raza, la clase con el género. Si el término «tercera ola» hace alusión al advenimiento de algo nuevo, se inserta en una genealogía que lo vincula con las dos olas anteriores: la primera, relacionada con el movimiento sufragista anglosajón para la obtención de los derechos cívicos y, la segunda, con el Movimiento de Liberación de las Mujeres en los años 70 que llegó a politizar las cuestiones sexuales popularizando los lemas «lo personal es político»y «nuestro cuerpo es nuestro».

La emergencia de una tercera ola nace de la movilización de las mujeres negras y las inmigrantes latinoamericanas a principios de los años 80 , quienes formularon críticas hacia el feminismo radical estadounidense de la segunda ola: para estas minorías étnicas o sexuales, la opresión no siempre era una opresión en razón del sexo sino de raza y/o de clase. A pesar de este primer cuestionamiento del feminismo hegemónico que se construyó en torno a la categoría de la mujer blanca, occidental, heterosexual y de clase media, la comunidad científica tardó en apropiarse el concepto de tercera ola aunque las reflexiones se iniciaran en las universidades estadounidenses desde la mitad de los años $90^{9}$.

En el espacio francófono varias investigaciones vieron la luz a partir de los años 2000 con el objetivo de dar cuenta de las mutaciones del feminismo contemporáneo ${ }^{10}$, pero las publicaciones se concentraron esencialmente en Canadá, a excepción de notables trabajos que vieron la luz en Francia: entre ellos figuran los de Elsa Dorlin ${ }^{11}$ y de Marie-Hélène/Sam

7 Faludi, 1993.

${ }^{8}$ En 1981, con la primera legislatura socialista de François Miterrand, se crea en Francia un Ministerio de los derechos de la mujer encabezado por Yvette Roudy.

${ }^{9}$ Findlen, 1995; Walker, 1995.

10 Nengeh Mensah, 2005 ; Blais «et al.», 2007 ; Oprea, 2008 ; Lamoureux, 2016 ; Baillargeon, 2011.

11 Dorlin, Bessin, 2005, p. 19. 
Bourcier ${ }^{12}$, que cuestionan directamente la mutación del sujeto unitario del feminismo, des-esencializándolo y obligándonos a descentrar la mirada sobre los retos que esperan a las feministas del tiempo presente.

Para Elsa Dorlin y Marc Bessin, la fecha de 1995 señala en Francia «un giro político y social» ${ }^{13}$ que se concreta en la organización por la CADAC $^{14}$ de una importante manifestación en favor de la defensa del aborto y de la contracepción. Esta movilización, que logró congregar a más de 40.000 participantes, señala un primer punto de inflexión porque al lado de «las feministas históricas y de las mujeres de la generación del MLF ${ }^{15}$ que desfilan en la calle para defender los derechos por los cuales habían luchado, encontramos también a sus hijas» ${ }^{16}$. El sociólogo francés Eric Fassin llega a la misma conclusión al afirmar que el debate en torno a la paridad en la década de los 90, «dividió, pero también volvió a revitalizar el feminismo» ${ }^{17}$, dando mayor visibilidad a sus prácticas y atrayendo a las generaciones de mujeres jóvenes.

Si la mayoría de las/os teóricas/os del feminismo están de acuerdo en localizar en la década de 1990 la mutación del feminismo y reconocer la renovación de su cultura militante y de sus estrategias de movilización, la categorización del feminismo en torno a la metáfora de las olas dista mucho de lograr un consenso entre la comunidad académica. Para algunas pensadoras feministas una «tipología pensada en términos de olas elimina la complejidad así como la diversidad de las teorías que recorren la historia del movimiento feminista ${ }^{18}$. Según la historiadora francesa Christine Bard, «esta división cronológica puede ser cuestionada. Una ola puede cubrir otra sin necesariamente desaparecer» ${ }^{19}$. Además, las reticencias a emplear el término se explican por el hecho de que «la tercera ola es más una cuestión de ideología que de generación» ${ }^{20}$. Pero a pesar de las controversias, las teóricas feministas comparten el sentimiento de que «algo nuevo está empezando» ${ }^{21}$ y que estamos asistiendo a una renovación de las teo-

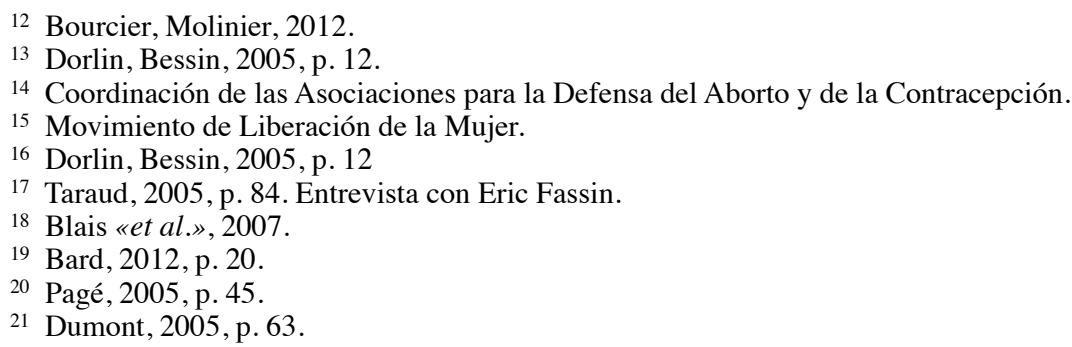


rizaciones, de las prácticas y de las subjetividades feministas. Si para algunas lo que «caracteriza al movimiento feminista no es ni el tiempo ni las generaciones sino las ideas» ${ }^{22}$, podemos comprobar que, en el espacio militante francés, los colectivos fundados en la década del 2000 son esencialmente el resultado de la movilización de feministas jóvenes ${ }^{23}$. Estos colectivos, amén de teorizaciones de muy diversa índole, responden a la definición que propone la socióloga Marina Cacace de los feminismos de la tercera ola:

«se trata de personas de unos treinta años que se identifican con las actitudes y los estilos (...) de la llamada Generación X y que - respecto a sus coetáneas feministas - mantienen una actitud más positiva para con el feminismo histórico y, aunque afirmando su propia identidad y estrategias específicas, se sitúan en una perspectiva de alianza intergeneracional como exponente de la segunda ola» ${ }^{24}$.

Para completar esta definición de los feminismos de tercera ola se pueden trazar algunos rasgos comunes: feminismos plurales, variedad de las sexualidades, desnaturalización de las identidades de género, centralidad y tecnologías del cuerpo, interseccionalidad, dimensión más autobiográfica del feminismo basado en la experiencia individual y usos de las nuevas tecnologías al servicio del activismo. El deseo común de acabar con «el feminismo de mamá» 25 anima a esas militantes jóvenes aunque parece demostrado que las discrepancias generacionales entre las feministas de la segunda y de la tercera ola son menores en Francia que en los Estados Unidos.

En Francia, las feministas jóvenes asumen la herencia de las históricas pero imprimiendo su propio estilo. Si elaboran nuevas estrategias de movilización acorde con su tiempo, muchas veces vuelven a tratar con una mirada nueva los grandes combates de los años 70 (defensa del aborto, igualdad salarial, reparto de las tareas domésticas, violencia de género, pornografía, prostitución), contradiciendo así el advenimiento de una era post-feminista que daría la ilusión que la igualdad real ha sido adquirida

22 Blais «et al.», 2007.

23 Pensamos en los colectivos Osez le féminisme (2008), La Barbe (2008), FEMEN France (2010), G.A.R.Ç.E.S (2010), Les efFRONTé-e-s (2011), FièrEs (2013), Georgette Sand (2014).

24 Cacace, 2006, p. 173.

25 Dorlin, Bessin, 2005, p. 20. 
y que el feminismo está obsoleto. A esta conclusión llega la historiadora canadiense Geneviève Pagé cuando afirma que «la tercera ola tiene como prioridad reanudar la lucha donde la dejó la segunda ola» ${ }^{26}$, así como la socióloga italiana Marina Cacace, quien señala que el feminismo de la primera ola y el de la segunda «coexisten hoy con los nuevos y diferentes feminismos que han ido emergiendo a partir del fin de los años setenta» ${ }^{27}$, y que esta convivencia se explica por el hecho de que los feminismos históricos no han podido conseguir los resultados que se habían propuesto.

No obstante, conviene valorar los avances conseguidos a lo largo de los últimos treinta años, tanto en el ámbito legislativo, educativo como laboral, lo que (re)actualiza los desafíos que se imponen al feminismo contemporáneo a raíz de las mutaciones políticas, sociales, culturales y tecnológicas. El reto de estos feminismos será conservar lo adquirido durante los últimos cuarenta años y seguir luchando por las libertades amenazadas $^{28}$, sin caer en la retórica de lo nuevo y sin borrar la memoria de lo que las luchas feministas pasadas han conseguido. Como lo expresa la antropóloga Lourdes Méndez Pérez:

«Ese borrar la memoria de las luchas feministas contribuye a su habitual clasificación como «nuevo» movimiento social, lo que no ayuda ni a restituir su historicidad, ni a comprender sus periódicas re-emergencias, ni a captar la heterogeneidad de un movimiento que desde finales de los sesenta del siglo XX no ha cesado de reinventarse» ${ }^{29}$.

Huelga recordar que a pesar de la articulación del feminismo en torno a tres olas, la especificidad del movimiento estriba en su discontinuidad, entre herencias, rupturas, huecos, etc., lo que condujo a la historiadora Karen Offen a elaborar otra metáfora inspirada en la naturaleza, al comparar la genealogía del movimiento feminista con los estratos geológicos sucesivos, las erupciones, las fisuras, los reflujos ${ }^{30}$. Obviamente, los años 90 son testigo de una proliferación de colectivos feministas, heterogéneos y a veces en conflicto abierto, pero que presentan la ventaja de ser portadores

\footnotetext{
26 Pagé, 2005, p. 47.

27 Cacace, 2006, p. 21.

28 Valcárcel, 2004.

29 Méndez Pérez, 2014, p. 14.

30 Offen, 2004, p. 38.
} 
de una mayor diversidad tal como lo demuestra la declinación del término en plural. Ahora bien, esta reivindicación de la pluralidad, muchas veces ensalzada como una novedad, no debe borrar el abanico de corrientes que convivieron en el movimiento feminista desde los años 70. Como señala Françoise Collin, el feminismo es por esencia «un espacio de enfrentamiento a partir de una protesta común del mundo que nos viene dado y de la voluntad de superarlo» ${ }^{31}$.

A pesar de las posturas divergentes, de las modalidades de actuación y de las estrategias múltiples del feminismo de tercera ola, «la comunidad feminista permanece unida en torno a una ética feminista mínima común» ${ }^{32}$ : el feminismo, asegura la historiadora francesa Christelle Taraud, sigue siendo «un laboratorio de lo político y de lo social, pero también y todavía una herramienta de conocimiento y de militancia reflexiva, performativa y subversiva ${ }^{33}$. Esta renovación del compromiso feminista y la consolidación de redes transnacionales dan cuenta de un movimiento de fondo que implica a una nueva generación de militantes deseosas de comprometerse en esta lucha universal que es la defensa de los derechos de las mujeres. Los colectivos que nos proponemos estudiar a continuación son emblemáticos de un resurgir del feminismo joven, porque a pesar de sus repertorios de acción, lenguajes y planteamientos diversos, desde el feminismo moderado hasta el activismo más radical, han adoptado estrategias de comunicación y formas de actuación que tienen como nexo común la visibilización del combate feminista mediante la utilización masiva de Internet y, en particular de las redes sociales.

Al margen de las cuestiones identitarias y sexuales, la tercera ola se plasmó a raíz de la revolución informática de los años 90, reconciliando así - bajo los efectos de la globalización - el feminismo y las nuevas tecnologías. Si desde sus inicios, «la tecnología fue considerada como una extensión de la dominación patriarcal y capitalista» ${ }^{34}$ en el seno del movimiento feminista, hoy en día esta tecnofobia va perdiendo arraigo. Las interacciones de las nuevas tecnologías con el género señalan un giro en la historia del feminismo ya que ciertas corrientes no dejaron de manifestar su pesimismo, por no decir su rechazo, hacia la tecnología. Fue el

\footnotetext{
31 Collin, Kaufer, 2005, p. 21.

32 Taraud, 2005, p. 14.

33 Ibid.

34 Wajcman, 2006, p. 49.
} 
caso del feminismo radical, del feminismo socialista o del ecofeminismo, que defendieron las tesis según las cuales las nuevas tecnologías, concebidas por los hombres y para un uso masculino, llevaban estampado el sello del patriarcado. En cambio, las nuevas generaciones de militantes han entendido que la tecnología podía convertirse en herramienta política al servicio del activismo feminista, y el ciberfeminismo, en una posibilidad subversiva contra el orden sexuado capaz de desestabilizar las estructuras patriarcales. La militancia en un mundo globalizado pasa por la conquista del ciberespacio, un «meta espacio» ${ }^{35}$ nuevo y dinámico, sin fronteras, que podría configurarse, desde una perspectiva de género, como el espacio privilegiado del nuevo activismo feminista y del empoderamiento de las mujeres.

Esta conquista del ciberespacio encuentra sus raíces en el ciberactivismo feminista australiano del colectivo VNS Matrix, quien publicó en 1991 su Manifiesto Feminista para el siglo XXI, y del colectivo Old Boy's, quien redactó las 100 antítesis del ciberfeminismo durante la primera conferencia internacional feminista en Alemania en 1997. Conforme a las tesis del ciberfeminismo, se trata de articular políticas de redes capaces de crear un «ecosistema informacional para introducir cambios profundos en la sociedad, romper el sistema jerárquico del poder y favorecer la estructura de redes, que permite devolver el protagonismo a la gente en la gestión de su vida y sus deseos» ${ }^{36}$. Lo que anunciaba Judy Wajcman en 2004 parece convertirse en realidad: «las mujeres están reinterpretando las tecnologías como instrumentos para la organización política y como medios para la creación de nuevas comunidades feministas» ${ }^{37}$. Si bien es cierto que «la globalización de comunicaciones es el aspecto positivo del nuevo mundo que se está construyendo» ${ }^{38}$, no resulta nada extraño que las feministas del siglo XXI hayan conquistado este espacio global y los recursos que ofrecen las tecnologías de la información para convertirlas en herramientas de la lucha feminista.

El desafío del ciberfeminismo consiste entonces en no «desaprovechar las posibilidades que las redes electrónicas ofrecen como herramienta de

\footnotetext{
35 Angustias Bertomeu, «Las mujeres dibujamos el mundo». <http://e-mujeres.net/ content/mujeres-dibujamos-mundo $>$. [23/09/2016].

36 Ibid.

37 Wajcman, 2006, p. 181.

38 Montserrat Boix, «Feminismos, comunicación y tecnologías de la información», 2002. <http://www.redfeminista.org/nueva/uploads/Montse\%20Boix.pdf>. [ 26/10/2016].
} 
transformación social» ${ }^{39}$ y en tomar en cuenta las posibilidades subversivas de las nuevas tecnologías para que el feminismo pueda abrirse un camino entre la tecnofobia y la tecnofilia. De hecho, la globalización de la información abre nuevos horizontes para el movimiento feminista, comenzando por construir «comunidades globales morales ${ }^{40}$, en las cuales las feministas dispondrían de una estructura común horizontal, el ciberespacio, con la capacidad de producir informaciones propias sin contar con los medios tradicionales, de coordinar luchas, de combatir la reproducción de estereotipos sexistas, de tender puentes de solidaridad internacionalizando el combate contra el patriarcado. En el siguiente epígrafe, nos proponemos ilustrar estas teorías a partir del ejemplo del colectivo feminista francés, Osez le Féminisme.

\section{El «feminismo de denuncia» del colectivo Osez le féminisme}

Fruto de la acción colectiva de un reducido grupo de mujeres jóvenes que se movilizaron para defender el Centro de Planificación Familiar francés amenazado por recortes presupuestarios, se creó en junio del 2009 el colectivo OLF (Osez le féminisme). Su fundadora, Caroline de Haas, antigua secretaria general del sindicato de estudiantes UNEF (Unión $\mathrm{Na}$ cional de los Estudiantes de Francia) tomó la iniciativa de levantar una «estructura de acogida, de reclutamiento y de organización de una nueva generación militante con el deseo de comprometerse en las cuestiones feministas» ${ }^{41}$. Es así como la red de OLF se puso en marcha y se federó en torno a algunos principios pilares: laicismo, progresismo, universalismo, antiracismo, abolicionismo ${ }^{42}$.

El Manifiesto fundador refleja las inquietudes de una nueva generación de mujeres, cuya edad oscila entre los veinte y los treinta años, la mayoría estudiantes, de clase media, que echaban en falta la existencia de espacios capaces de movilizar colectivamente a una nueva generación de militantes. Identificadas con el feminismo de la igualdad, mantienen una

39 Ibid.

${ }^{40}$ Cobo, 2005, p. 273.

${ }^{41}$ Eliane Viannot, Colloque 40 ans de pratiques féministes en Ile de France, 5/06/2010. <http://www.elianeviennot.fr/Articles/Viennot-Parcours-40ans.pdf>. [4/09/2016].

${ }_{42}$ Charte des valeurs communes de l'Association, mayo de 2012. <https://app.box. com/s/c3f15cc0b9cdae69fadb>. [15/12/2016]. 
continuidad con los combates feministas históricos de la segunda ola y, en este sentido, la trayectoria del colectivo es representativa del despertar feminista de las nuevas generaciones que rompen con el discurso dominante según el cual «las jóvenes no quieren comprometerse en un movimiento de mujeres porque piensan que ya no es necesario» ${ }^{43}$. Para acabar con el recelo que las jóvenes parecen experimentar en su relación con el feminismo, las militantes de OLF eligieron incorporar de forma visible el término feminismo en el mismo nombre del colectivo: de este modo se trataba de (re)legitimar el feminismo, como movimiento de protesta política y social, frente a la trivialización de la que era objeto en los medios de comunicación y en la sociedad en genera ${ }^{44}$. En su Manifiesto, dejan claro que «la evolución de los derechos de las mujeres se ha detenido y lamentamos los retrocesos reales en ciertos ámbitos ${ }^{45}$, lo cual refeja que quieren mantener un diálogo intergeneracional y una filiación intelectual con las feministas históricas de la segunda ola.

Si el objetivo es preservar ese legado feminista, actúan sin embargo con los medios a su alcance, incorporando en su praxis las nuevas tecnologías como herramienta de activismo y de empoderamiento. La ocupación de la red por parte de estas ciberfeministas responde a un objetivo político en la medida en que se trata de cuestionar el universo androcéntrico de la red elaborando lenguajes y prácticas autónomos. Las militantes de OLF, a imagen de su antigua portavoz, Caroline de Haas, concuerdan en que «lo que nos diferencia de las feministas de los años 70 , es internet» ${ }^{46}$, un postulado nada extraño puesto que esta generación joven se ha criado con las nuevas tecnologías y las ha incorporado de forma natural a su praxis militante. En palabras de otra militante de OLF, «internet es una herramienta que permite federar, informar, coordinar luchas» ${ }^{47}$, lo que explica que todas las campañas del colectivo encuentren un eco mediático por el efecto

43 Cacace, 2006, p. 122.

44 «El debate entre nosotras consistió en decidir si debía aparecer claramente el término «feminismo» en el nombre del colectivo. Finalmente dijimos que sí, que teníamos que asumirlo y no reivindicar otra cosa». Entrevista de la autora con Iris Naud, militante de OLF, París, 29 de octubre de 2011.

${ }_{45}$ Texte de lancement du Réseau, junio de 2009. <http://www.osezlefeminisme.fr/article/texte-de-lancement-du-reseau>. [ 23/09/2016]

46 «Les nouvelles féministes mettent les points sur les i», Telerama, 27/07/2011. $<$ http://www.telerama.fr/idees/les-nouvelles-feministes-mettent-les-poings-sur-les-i,71332. php>. [23/09/2016].

47 Entrevista de la autora con Iris Naud. 
multiplicador que tiene el ciberespacio: las redes sociales y, Twitter en particular, ofrecen la ventaja de ser unos espacios transnacionales en los que navegan usuarios que se sitúan al margen de los circuitos feministas, como los políticos, los periodistas o los blogueros.

Paralelamente a la página web de la organización, consultada por una media de 11.000 internautas al mes, y a su cuenta Twitter, el activismo de OLF se consolida en torno a su página Facebook que cuenta con más de 100.000 seguidores. Este uso político de las redes de comunicación ha dado buenos resultados como lo ejemplifica el éxito institucional de una de las campañas a favor de la eliminación de «la casilla señorita» ${ }^{48}$ en los formularios administrativos, que fue denunciada por ser una práctica discriminatoria para las mujeres y una seña del sexismo ordinario que perdura en la sociedad francesa. Gracias a la movilización digital como arma de lucha y de presión, el Gobierno francés accedió en 2012 a que se suprimiera oficialmente la casilla en todos los formularios administrativos.

Como admiten todos los expertos en nuevas tecnologías, «intentar cambiar el mundo a golpe de ratón es una nueva forma de movilización juvenil» ${ }^{49}$, e Internet aparece en este sentido como «una auténtica revolución social en la cultura juvenil (...) y un nuevo agente de socialización ${ }^{50}$, lo cual se puede aplicar a la mayoría de los grupos feministas que se formaron en la década de los 2000. Prueba de ello es el auge de los nuevos espacios militantes gestionados por las feministas francesas: portales digitales, páginas web, blogs, foros, redes sociales, Tumblr. Los blogs, en la mayoría ideados por feministas jóvenes, buenas conocedoras de la cultura de la comunicación, adquirieron estos últimos años una amplia visibilidad en la cultura militante . Actúan como un motor de liberación de la palabra de las mujeres invisibilizadas tal como lo indica Montserrat Boix:

«Los blogs, las redes sociales (Twitter, Facebook) nos permiten compartir de manera masiva, viral y en tiempo real mensajes, campañas, contenidos y proyectos conectados con la realidad virtual y presen-

${ }^{48}$ Hasta esta fecha, las mujeres francesas tenían que elegir entre Mademoiselle o Madame en función de su estado matrimonial a la hora de rellenar un formulario público. Dos colectivos feministas, OLF y Les chiennes de garde lanzaron la campaña para suprimir esta casilla.

49 Trilla, 2011, p. 215.

50 Ibid. 
cial. La internet se ha convertido en una herramienta estratégica con potencialidad para cambiar el marco cultural hegemónico» ${ }^{51}$.

El blog participa de estas estrategias para combatir la invisibilización de lo femenino y ha permitido, desde una perspectiva de género, sacar a la luz el sexismo sufrido por las mujeres en el mundo laboral o en su vida cotidiana tal como lo desvela el éxito del blog de OLF, Vie de Meuf: en 6 meses, 1200 anécdotas fueron colgadas y la página recibió más de 720.000 visitas.

Este experimento reciente nos induce a preguntarnos: $i$ se está convirtiendo el blog en una nueva herramienta de la militancia feminista contemporánea ? La respuesta es positiva si partimos de la premisa de que es un instrumento de comunicación directo, gratuito, autónomo que permite articular la dimensión entre la esfera pública y privada y que propone una lectura alternativa al discurso monolítico de los medios institucionales. El blog concede «valor al espacio de los márgenes» ${ }^{52}$ por el hecho de fomentar la interacción entre las mujeres, y, en cierto modo, (re)actualiza el principio de sororidad popularizado por las feministas de la segunda ola que organizaron grupos de autoconciencia no mixtos con la «virtud de conectar cada vivencia solitaria e individualizada con una experiencia colectiva ${ }^{53}$. Dicho de otro modo, se trata de hacer visibles e incluso de politizar experiencias de sexismo ordinario interiorizadas o silenciadas que vuelven a cobrar sentido en el espacio público mediante las redes. Los blogs se convierten en «un cuarto propio conectado» para retomar la imagen potente de Virgina Woof, conceptualizada desde una perspectiva más actual por la escritora española Remedios Zafra, para quien «es, en esa necesidad del otro, donde lo privado se hace público como la esfera del «cuarto propio conectado». Allí es donde nuestra fragilidad es puesta sobre la mesa y es compartida» ${ }^{54}$.

Estas jóvenes feministas están demostrando que no se pueden combatir las discriminaciones sin reinventar nuevas estrategias y repensar la estética del movimiento feminista, más acorde con su tiempo, dinámico

51 Montserrat Boix, «Desde el ciberfeminismo hacia la tecnopolítica feminista», Revista Pillku, «Ciberfeminismo», $\mathrm{n}^{\circ}$ 18, septiembre de 2015. <http://www.pillku.org/article/ desde-el-ciberfeminismo-hacia-la-tecnopolitica-fem/>. [05/12/2016].

${ }_{52}$ Marsili, 2010, p. 109.

53 Gil, 2011, p. 56.

54 Zafra, 2010, p. 81. 
y horizontal, capaz de articular la militancia de terreno, más local, y la militancia on line, más global. La potencialidad de un «ir y venir entre la calle y el ciberespacio» ${ }^{55}$ fortalece el activismo feminista, que se visibiliza y repercute en la movilización de las mujeres en diferentes partes del mundo. Sin embargo, es justo reconocer que estos colectivos jóvenes en red muchas veces se dirigen a un público bastante homogéneo: el de las estudiantes y/o jóvenes occidentales de clase media que tienen acceso a las nuevas tecnologías. Las críticas que se formulan denuncian un feminismo un tanto elitista por parte de asociaciones que elaboran una agenda política al margen de las vivencias de las mujeres precarias, obreras, inmigrantes, etc., por no hablar de las millones de mujeres que no tienen acceso a Internet debido a la brecha digital. Un balance autocrítico que asumen las militantes de OLF: como confiesa una de sus afiliadas, «somos muy parisinas, muy urbanas, nuestro feminismo no deja de ser algo entre comillas burgués, aunque no significa que todas las militantes sean burguesas reales pero son chavalas con niveles de estudios altos y que, en su mayoría, nunca las han pasado canutas» ${ }^{56}$. Asimismo, todas confían en un relevo generacional potente y aunque hay conexiones con las feministas históricas y sus luchas compartidas, las modalidades de acción - gracias a las nuevas tecnologías - difieren notablemente colocando al feminismo en una esfera más global tal como señala Marina Cacace:

«la novedad es que, gracias a las nuevas tecnologías y a los aspectos culturales y comunicativos de la globalización, lo que sucede a nivel local tiene siempre mayor importancia a nivel global, y la posibilidad de ser conocido, adaptado y replicado en cualquier parte del mundo» ${ }^{57}$.

Muchas veces las feministas jóvenes se diferencian de sus antecesoras por su capacidad de reacción a la hora de difundir o mediatizar sus propuestas, sacando el feminismo de los círculos privados para colocarlo, de forma transversal, en el centro de los debates políticos y sociales adqui-

55 Angélica Schenerock, «Subversiones y rebeldías en el ciberespacio», Revista Pillku, «Ciberfeminismo», $\mathrm{n}^{\circ} 18$. <https://pillku .org/article/subversiones-y-rebeldias-en-el-ciberespacio/>. [5/12/2016].

56 Entrevista de la autora con Iris Naud.

57 Cacace, 2005, p. 205. 
riendo así el poder «de ser creativas, forjadoras de ideas y deseos propios $-\mathrm{y}$ no consumidoras o repetidoras de ideas y deseos ajenos» ${ }^{58}$.

Las mujeres, desde el espacio en red, están construyendo un contrapoder a la sociedad capitalista, patriarcal, heteronormativa, tal como lo demuestra otro colectivo francés cuya trayectoria ejemplifica este empoderamiento mediante el activismo en red. Se trata de un colectivo joven y mixto, Georgette Sand, formado por un grupo de jóvenes en agosto de 2014: joven porque la edad media de los/las militantes se sitúa en los treinta años; mixto porque era su voluntad «implicar a los hombres para hacer entender que ellos también pueden militar en favor de la justicia social, que ellos también pueden encontrar las normas de género apremiantes ${ }^{59}$. Asumen el carácter mixto sin que ello suponga un protagonismo masculino que relegaría a un segundo plano las iniciativas y experiencias de las militantes e incorporan el humor como forma de militancia, como indica el nombre del colectivo, que es un guiño a la escritora francesa George Sand, quien adoptó un seudónimo y una indumentaria masculinos para poder publicar sus libros. Para las/los militantes del colectivo Georgette Sand, la feminización del nombre «George» con el diminutivo «Georgette» era una manera lúdica de cuestionar la necesidad de llamarse George y de vestir a lo masculino para ser tomadas en serio en la sociedad.

En el Manifiesto publicado en su página web argumentan que su ambición es «combatir las visiones esencialistas que consideran como naturales la seguridad de los hombres y la reserva de las mujeres cuando en realidad se trata del resultado de una construcción educativa» y apelan a «trasgredir y subvertir las normas de género» ${ }^{60}$. Sin ser un colectivo que pueda contar con medios económicos ni con muchos activistas $^{61}$, este grupo se dio a conocer por las redes con una campaña contra la «tasa rosa» o el llamado marketing de género: sencillamente por unos mismos productos de la vida cotidiana, como las cuchillas de

58 Angélica Schenerock, «Subversiones y rebeldías en el ciberespacio», Revista Pillku, «Ciberfeminismo», $\mathrm{n}^{\circ}$ 18. <https://pillku.org/article/subversiones-y-rebeldias-en-el-ciberespacio/>. [5/12/2016].

${ }_{59}$ Entrevista de la autora con Géraldine Franck, antigua militante del colectivo Georgette Sand, 2 de diciembre de 2015.

$60<\mathrm{http} / /$ www.georgettesand.org/manifeste/>. [24/10/2016].

${ }^{61}$ El colectivo cuenta con unos veinte activistas pero respaldados por unos cien «simpatizantes»: Entrevista por correo electrónico de la autora con Gaëlle Couraud del colectivo Georgette Sand, 2 de diciembre de 2015. 
afeitar, las mujeres pagan más caro que los hombres. Después de haber llevado a cabo una comparación de precios, dieron a conocer los primeros resultados e interpelaron a la clase política, en particular al Ministro de Economía. A raíz de esta primera iniciativa, Gorgette Sand afrontó otro problema proponiendo rebajar el IVA de los productos para la higiene femenina gravados con un $20 \%$. La propuesta buscaba eliminar este «impuesto sobre el tampón» y rebajarlo en un 5,5\%, defendiendo el carácter de primera necesidad de estos productos y arguyendo que las consumidoras no tienen otras alternativas. Después de un primer voto negativo en el Congreso, el Senado terminó por votar, el 21 de noviembre de 2015, a favor de la reducción del IVA en un 5,5\%, lo cual representó una primera victoria médiatica para el colectivo y, al mismo tiempo, para el activismo en red: la petición que fue difundida en la plataforma change.org logró reunir más de 27.000 firmas, demostrando la centralidad de las nuevas tecnologías en la práctica militante feminista contemporánea.

Estas iniciativas llevadas a cabo por colectivos de creación reciente confirman cómo el activismo en red en manos de una nueva generación militante logra buenos resultados a la hora de conseguir reformas como la casilla Mademoiselle en el caso de OLF, o la tasa rosa en el caso de Georgette Sand, que si bien pueden parecer anecdóticas, son reveladoras de las discriminaciones ordinarias que afectan la vida cotidiana de las francesas. Además, OLF ha adquirido en algunos años una amplia atención mediática con campañas de gran calado en las redes: contra la violación, contra el feminicidio, contra el acoso callejero y el acoso sexual en los transportes públicos, en favor de la (re)legitimación del clítoris y de la sexualidad femenina, en defensa del aborto y en contra del sistema prostituyente, defendiendo una postura abolicionista claramente asumida. Todo esto le ha permitido convertirse en la asociación feminista más joven de referencia en Francia. A pesar de las críticas en contra de su feminismo elitista y de la homogeneidad del perfil de sus militantes, OLF ha conseguido ampliar sus bases reclutando nuevos/as socios/os y abriendo secciones en varias ciudades francesas que coordinan estrategias de luchas y campañas con notables repercusiones en el ámbito regional.

No obstante este feminismo, que pide reformas legales en la línea del feminismo de la igualdad, convive con otras formas de movilización, inspiradas en el activismo radical, con el propósito de desgajarse del feminismo de Estado, del feminismo onusiano y del feminismo académico y que postulan por un «feminismo de la calle» contra un «feminismo de 
cátedra» ${ }^{62}$. De hecho, ciertos colectivos feministas abogan por la reintroducción de la no-mixidad y del activismo radical en sus repertorios de actuación, lo cual es también propio de algunas culturas juveniles urbanas. Esta constatación no es exclusiva de Francia tal como lo podemos comprobar en otras áreas culturales o geográficas: en España los colectivos feministas autónomos surgidos a raíz del 15-M son un buen ejemplo de una renovación de la militancia juvenil y radical que se benefició de la crisis para desarrollar otras prácticas y moldear nuevos lenguajes ${ }^{63}$. En este apartado, nos vamos a centrar exclusivamente en la trayectoria del colectivo Femen por el alcance mediático que ha adquirido, no sólo en Francia, sino a escala internacional, llegando a convertirse, no exento de polémicas, en un movimiento emblemático que asume otro tipo de feminismo: joven, radical y transnacional.

\section{FEMEN: el «sextremismo» como nueva forma de activismo feminista}

El colectivo Femen inició su andadura en 2008 a iniciativa de tres estudiantes marxistas ucranianas, Anna Hutsol, Oksana Chatchko et Sacha Shevchenko que querían combatir la opresión de la sociedad patriarcal y la explotación del cuerpo de las mujeres a través de las redes de prostitución y del turismo sexual. La ideóloga histórica del movimiento, Anna Hutsol, logró agrupar a un núcleo de activistas jóvenes que compartían el deseo de entrar en resistencia contra el sistema patriarcal y sus instituciones. La táctica, inspirada en el marketing y la comunicación, consistía en cosechar un eco mediático realizando acciones provocadoras y espectaculares porque un colectivo según Hutsol, «debe ser popular, generar emociones, excitación. La gente siempre se interesará más por el color de las bragas de las famosas que por las conferencias feministas» ${ }^{64}$.

Si las primeras acciones se celebraron en territorio ucraniano, el grupo fue perfeccionando sus estrategias con el reclutamiento de una nueva militante, Inna Shevchenko. A partir del año 2010 estas jóvenes feministas empezaron a encararse contra representantes del orden político (el presidente ruso Vladimir Putin) o de la jerarquía eclesiástica (el Patriarca de

62 Lamoureux, 2006, p. 194.

63 Bergès, 2014.

64 «L'internationale féministe», Le Monde, 17/02/ 2013. <http://www.lemonde.fr/a-laune/article/2013/02/16/l-internationale-feministe_1833783_3208.html>. [15/09/2016]. 
la Iglesia ortodoxa rusa Kirill) y protagonizaron una serie de performances transgresoras como la que consistió en derribar con una motosierra una cruz católica de siete metros de alto, instalada ilegalmente en tiempos de la Revolución Naranja, en el centro de Kiev. Como consecuencia de su activismo, simpre al borde de la legalidad, las militantes del colectivo sufrieron represalias físicas y amenazas de muerte que las obligaron a exiliarse ${ }^{65}$.

Inna Shevchenko, la líder actual del movimiento Femen Europa, llegó a París en agosto de $2012^{66}$ donde fue acogida por unas cuantas feministas francesas, cercanas al grupo Ni Putes ni Soumises ${ }^{67}$. Desde el cuartel general parisino, se inició la expansión del colectivo en el ámbito internacional a partir de tres pilares comunes: la lucha contra las dictaduras, contra la industria del sexo y contra las religiones ${ }^{68}$. Como la mayoría de los colectivos que se identifican con la tercera ola, las activistas no separan el feminismo de las cuestiones económicas, políticas, religiosas o culturales. En este sentido, las Femen se vinculan con los feminismos de la última generación que reivindican la transversalidad de sus planteamientos y, así lo expresan en la obra colectiva que redactaron en $2013^{69}$ y en su Manifiesto de 2015, «a la vez derecho de respuesta política, acervo ideológico y manual de instrucción dirigido a las futuras activistas de Femen ${ }^{70}$. En sus escritos, las ideólogas teorizan sobre el concepto clave del movimiento, «el sextremismo» definido como:

«la sexualidad femenina que se rebela contra el patriarcado mediante acciones políticas frontales y radicales (...) una forma de provocación no violenta pero sumamente agresiva, un arma poderosa de desmoralización, que socava los cimientos de una ética polvorienta y de una cultura patriarcal emponzoñada $»^{71}$.

65 Para más detalles véanse, Fourest, 2014.

66 Inna Shevchenko llegó a París con un visado turístico en 2012 y obtuvo el asilo político en Francia en abril de 2013.

${ }^{67}$ Ni Putes Ni Soumises es un colectivo feminista fundado en 2003 por jóvenes de los suburbios franceses.

68 Véase Bergès, 2015. «L'internationale féministe», Le Monde, 17/02/ 2013. <http:// www.lemonde.fr/a-la-une/article/2013/02/16/1-internationale-feministe_1833783_3208. html>. [15/09/2016].

69 Femen, 2013.

${ }^{70}$ Este Manifiesto Femen fue publicado en varios idiomas. Aquí utilizaremos la traducción española de Aragón, 2015, p. 11.

${ }^{71}$ Ibid., p. 58. 
Si al principio, el topless no logró consenso entre las activistas históricas $^{72}$, rápidamente se impuso como el nexo común y la cara reconocible del colectivo. Durante las performances, los pechos y el vientre están al descubierto y se exponen a la mirada, la cabeza está coronada de flores, símbolo de virginidad en Ucrania pero que las Femen reinterpretan como «el emblema de la mujer luchadora, orgullosa, libre e insumisa» ${ }^{73}$ y el cuerpo, cubierto por pintadas y eslóganes, se convierte en una herramienta en contra del sistema patriarcal dominante. Como confirma Lara Alcázar, la líder de Femen España «es importante el hecho de que no perdamos la premisa de que el cuerpo es un elemento que no se puede perder porque el hecho de ir en topless no habla sólo de la doble moral que existe, el hecho de ir en topless representa saltarse todas las normas ${ }^{74}$. El cuerpo de la mujer, tradicionalmente asociado con la sexualidad o la pornografía, se desprende de su función erótica o mercantil para convertirse en un uniforme político que denuncia la opresión de las mujeres. Para las Femen, el objetivo consiste en utilizar sus torsos como pancartas, en convertir sus cuerpos en «cuerpos discursos» ${ }^{75}$, táctica que les permite exhibir un mensaje pintado en mayúsculas negras, corto, impactante y fácilmente comprensible en cualquier parte del mundo. La oposición o la indignación se expresan en términos corporales porque el cuerpo, nos dice Judith Butler, habla políticamente:

«La persistencia del cuerpo pone la citada legitimidad en tela de juicio y lo hace precisamente a través de una performatividad del cuerpo que atraviesa el lenguaje sin reducirse a lenguaje. En otras palabras, no es que la acción corporal y los gestos tengan que traducirse al lenguaje, sino que tanto la acción como el gesto significan y hablan, como acción y como demanda, y que ambas cosas están entrelazadas de forma inextricable». ${ }^{76}$

En definitiva, las Femen reivindican la reapropiación performativa del cuerpo como sujeto político, un sujeto que grita, un sujeto activo, un sujeto que expresa su indignación. Su lema «nuestro cuerpo es nuestra

72 Véanse el testimonio de Inna Shevchenko, Femen, 2013, p. 115.

73 Manifiesto Femen, 2015, p. 62.

${ }^{74}$ Entrevista de la autora con Lara Alcázar, líder Femen España, Madrid, 4 de noviembre de 2015.

75 Paveau, 2013.

76 Butler, 2012. 
arma» funciona como una metáfora: la metáfora del seno liberado es la metáfora de la liberación de la mujer.

Si la desnudez como herramienta política suscita mucho rechazo o incomprensión, conviene recordar que es un repertorio de acción que no es nuevo: fue adoptado por los anarquistas libertarios del siglo XIX, los movimientos pacifistas de los años 70, el accionismo vienés de la segunda mitad de los 60 e incluso por el movimiento feminista de la segunda ola cuya revolución consistió en poner el cuerpo en el foco de las miradas y en politizar la sexualidad. También el uso de la desnudez y de los eslóganes fueron incorporados en las performances conceptuales de la artista feminista española, Esther Ferrer, desde mitad de los años 60. Más conocida en Francia que en España, donde vive desde hace más de treinta años, sigue realizando con setenta y siete años performances en las que el cuerpo desnudo sigue siendo una herramienta política, feminista y artística. En cambio, lo que sí es inédito en la historia de la militancia feminista es el uso de los eslóganes para «vestir» los cuerpos marciales de las militantes tal como lo reconocen algunas historiadoras del feminismo ${ }^{77}$ y las propias Femen, cuando afirman que «los cuerpos de las activistas muestran una nueva estética en la historia del combate feminista ${ }^{78}$.

De hecho, esta forma de activismo no ha dejado de levantar críticas que se concentran, en el caso de Femen, en la violencia del colectivo, aunque a nuestro parecer, sería más adecuado hablar de una violencia simbólica o de una puesta en escena de la violencia, ya que no dañan la integridad física de las personas sino que realizan acciones colectivas transgresoras y agresivas en contra de las instituciones más patriarcales, y en particular, religiosas. Pero bien es cierto que a las militantes les gusta jugar con la ambigüedad: cuidan una estética de amazonas intrépidas dispuestas a recibir los golpes y al mismo tiempo, juegan con la vulnerabilidad debida al cuerpo femenino desnudo, expuesto a la brutalidad de sus adversarios. Asimismo, la frontera entre lo guerrero y lo erótico es difusa, lo que les ha valido numerosas críticas de las feministas francesas, y en particular de los grupos LGBT quienes critican la primacía del sujeto

77 Véanse las declaraciones de la historiadora francesa Christine Bard, Roads Actualités, 19/02/2014. <http://roadsmag.com/christine-bard-la-violence-des-femen-est-symbolique190220140775594674/>. [25/09/2016].

78 Manifiesto Femen, 2015, p. 55. 
«mujer» y el binarismo de género defendido por Femen ${ }^{79}$ y se ensañan contra su estética sexuada, la de un cuerpo conforme a los cánones de belleza occidental heteronormativos: mujeres blancas, rubias, altas, delgadas y jóvenes ${ }^{80}$. En contra de esta acusación, las Femen argumentan que invierten la connotación misógina ligada a la desnudez femenina adoptando una actitud de rebeldía (los gritos que deforman sus caras, el no sonreír nunca en las acciones, el porte marcial) la cual no encaja con los roles clásicos de seducción: «lo que choca en las acciones de Femen es la imagen de la sublevación de mujeres que en apariencia corresponden punto por punto a los códigos que las han tenido siempre sometidas» ${ }^{81}$. Esta estética guerrera rompe con la imagen de la desnudez canónica y transforma el cuerpo en «cuerpo político», de ahí la identificación de las Femen con alegorías nacionales como la Marianne republicana o la asociación con el retrato de Delacroix, La liberté guidant le Peuple. Las mismas militantes cultivan la iconografía de nuevas amazonas del feminismo como podemos leer en su primer Manifiesto:

«Las activistas FEMEN son mujeres especialmente formadas física y psicológicamente preparadas para realizar tareas humanistas con un grado elevado de complejidad y de provocación. Las activistas FEMEN están dispuestas a sufrir represiones, y su motivación no es sino ideológica. Femen es el comando del feminismo, su vanguardia de combate, una encarnación moderna de amazonas intrépidas y libres» ${ }^{82}$.

A nuestro juicio, es necesario incidir en la espectacularización de la imagen de las Femen y no se debe ocultar la dimensión simbólica y emocional del compromiso. Los testimonios de las sextremistas reflejan la vo-

79 «Yo creo que en Femen hablamos en plan de términos binarios muchas veces pero no negamos la diversidad dentro de los seres humanos, respetamos muchísimo eso, hemos luchado siempre por la integración del matrimonio LGTB, es decir hemos estado siempre allí, no, y realmente no existe ningún motivo para que nosotras no aceptemos, como ya hemos hecho, activistas que representen cualquier otro tipo de identidad siempre que se denominen como mujer, si es una mujer CIS, si es una mujer trans pero que lo que a ti te represente sea la identidad mujer», entrevista de la autora con Lara Alcázar.

80 Véase el artículo del colectivo feminista francés G.A.R.C.E.S, «Les Femen ou la stratégie de l'échec», 19 de julio de 2013. <http://collectiffeministe.wordpress. com/2013/07/19/les-femen-et-la-strategie-de-lechec/>. [10/12/2016].

${ }^{81}$ Manifiesto Femen, 2015, p. 64.

82 Femen, 2013, p. 8. 
luntad colectiva de reanudar un activismo primario: se trata de comprometerse con una causa, mental y físicamente, para distanciarse del feminismo académico o institucional, como recuerda la líder del movimiento, Inna Shevchenko, quien establece una clara diferencia entre las que practican el feminismo y las que lo teorizan. De este modo, vincula el colectivo con los movimientos sociales contestatarios que reanudan con un feminismo de acción directa y desobediencia civil transformando el espacio público en territorio de resistencia:

«Lo que conlleva la idea de una tercera ola, es la posibilidad de una radicalidad del feminismo, cuando lo que domina hoy en día, en muchos países, es un feminismo institucional, que procede, claro, de una ola militante pero que ha borrado parcialmente sus orígenes para conseguir un reconocimiento tanto en los sistemas nacionales de gestión de las poblaciones como en un sistema mundial de gobernanza» ${ }^{83}$.

Cuando, el 9 de octubre de 2013, Lara Alcázar y dos activistas de Femen Francia - Inna Shevchenko y Pauline Hillier - interrumpieron en las Cortes el discurso del Ministro de Justicia española, Alberto Ruiz Gallardón, promotor del proyecto de reforma sobre el aborto, fue con la intención de «meter la calle en las instituciones (...) ocupar el espacio de confort de la clase política (...) y obligarla a escuchar el mensaje que no quiere escuchar en la calle» ${ }^{84}$, lo que aproxima su acción a la noción de «ocupación performativa de los edificios» teorizada por Judith Butler ${ }^{85}$.

En Francia, estas formas de movilización que mezclan acción directa y desobediencia civil encuentran sus raíces en la tradición libertaria de finales del siglo XIX, el sindicalismo y el movimiento obrero. Sin embargo, desde los años 2000 asistimos a un resurgir de la acción contestataria a iniciativas de colectivos jóvenes, minoritarios y con alcance mediático, entre los cuales figuran las Femen. Sin embargo, la ocupación del espacio público por grupos de mujeres tampoco es inédita en la historia del movimiento feminista si recuperamos la memoria de las acciones transgresoras de las feministas históricas de la primera ola. A principios del siglo XX, las

\footnotetext{
${ }^{83}$ Lamoureux, 2016, p. 207.

84 Entrevista de la autora con Laura Alcázar.

85 Butler, 2012.
} 
sufragistas de la WSPU (Women's Social and Political Union) fundada en 1903 por Emmeline Pankhurst ${ }^{86}$, adoptaron formas de protesta de desobediencia civil y popularizaron el lema «Deeds not Words» (Palabras no, actuaciones sí). Las activistas británicas perturbaban las reuniones políticas, se encadenaban a las rejas del parlamento, rompían escaparates, incendiaban o saboteaban edificios públicos, lo que les valió la detención y hasta la tortura durante sus estancias en la cárcel.

Del mismo modo se puede establecer una continuidad con las feministas francesas de la segunda ola quienes adoptaron repertorios de acción radicales en el espacio público e incorporaron en sus prácticas la insolencia, el humor, la transgresión etc., heredados de Mayo del 68, para enfrentarse a los poderes institucionales y al orden patriarcal. A modo de ejemplo, citemos la fecha del 26 de agosto de 1970 cuando una decena de mujeres depositaron un ramo de flores en la tumba del soldado desconocido, en el Arco de Triunfo de París, dedicado a la mujer del soldado desconocido con un lema: «Existe alguien más desconocido que el soldado desconocido, su mujer». Asimismo, habría que mencionar las movilizaciones a favor del aborto y de la libre disposición de su cuerpo, como el famoso Manifiesto de las 343 en abril de 1971o las manifestaciones de noviembre del mismo año ${ }^{87}$. Como señala la investigadora y activista histórica Françoise Picq: «la perspectiva era radical: no se trataba de mejorar la condición de las mujeres en la sociedad, de obtener más derechos, más igualdad sino de cambiar la sociedad, puesto que se basa en la opresión y en la explotación de las mujeres ${ }^{88}$.

Más recientemente, este activismo directo ha sido recuperado por otro colectivo feminista francés, La Barbe. Groupe d'action féministe, fundado el mismo año que Femen en 2008 por una antigua activista de Act up París, Marie de Cenival. Como indica una de las militantes de este colectivo que también performa el cuerpo, «a su manera las Femen reanudan un feminismo de los orígenes ${ }^{89}$. Esta cultura de un feminismo de acción directa se explica entre otras cosas por el perfil atípico de las militan-

86 Pankhurst, 2015.

87 Sobre la historia de los feminismos de la segunda ola en Francia véanse Sarcey, 2002 ; Picq, 2010 ; Bard, 2012.

88 Picq, 2008, p. 71

${ }^{89}$ Declaración de la periodista y feminista francesa Alice Coffin, «L'internationale féministe», Le Monde, 17/02/2013.http://www.lemonde.fr/a-la-une/article/2013/02/16/1-internationale-feministe_1833783_3208.html. [15/09/2016] 
tes Femen: mujeres jóvenes entre veinte y treinta años, la mayoría sin una trayectoria militante anterior pero con una entrega total hacia una causa común que conciben como una lucha universal contra el patriarcado. Reivindicando un «pop feminismo», combativo pero glamuroso, se esmeran en cultivar una imagen que no deja de recordar en cierto modo a las heroínas híper-sexuadas y guerreras de los videojuegos, buscando desmarcarse del arquetipo de la feminista clásica. Sin embargo, en algunas ocasiones las Femen echaron a perder el apoyo de sus aliadas feministas como cuando Inna Shevchenko declaró que «las feministas no son mujeres ancianas escondidas detrás de sus libros» ${ }^{90}$. A pesar de los tropiezos cometidos, de los malentendidos y de la diferencia cultural entre las feministas ucranianas y francesas, la mayoría de las jóvenes que militan en el colectivo consideran que Femen renueva el lenguaje, la estética y las prácticas feministas dando la primacía a la acción directa sin caer en la pedagogía del feminismo de denuncia o institucional, tal como reconoce esta activista de Femen Francia: «el papel de las Femen es poner el dedo en la llaga (...) el trabajo de fondo le corresponde más a Osez le féminisme. Nosotras planteamos actos de resistencia» ${ }^{91}$.

El interés del colectivo, a nuestro parecer, radica en el perfil atípico de sus militantes que no se ponen ningún límite y en sus estrategias transnacionales que se exportan más allá de las fronteras nacionales. Este colectivo minoritario, que vio la luz en un contexto específico de la dictadura ucraniana, consiguió en apenas unos años un eco internacional inédito abriendo nuevas secciones en varios países, gracias al uso político de las nuevas tecnologías que incrementaron el impacto mediático de Femen a partir de su página traducida a varios idiomas y diferentes páginas de $\mathrm{Fa}$ cebook y cuentas de Twitter. Esta estructuración reticular es particularmente eficaz, ya que la horizontalidad y el efecto multiplicador de la red garantizan una difusión masiva de la propaganda, un control sobre las informaciones que las activistas quieren hacer públicas y una visibilidad a escala internacional.

Si la estrategia se limita a alimentar cotidianamente sus respectivas páginas web con las mismas informaciones traducidas a varios idiomas

90 Quentin Girard, «Inna Shevchenko. Un esprit sein», Libération, 17/15/2012.<http:// next.liberation.fr/sexe/2012/09/17/inna-shevchenko-un-esprit-sein_846924>. [15/09/2016].

${ }^{91}$ Declaración de Marguerite Stern, «Femen : Des hauts \& débats », Causette.fr, 25/02/2013. <https://www.causette.fr/le-mag/lire-article/article-547/femen-des-hauts-dabats.html>. [15/09/2016]. 
y con las fotografías de sus performances más espectaculares, es cierto que les proporciona un amplio eco mediático pero las convierte a la vez en blanco del odio racista, sexista y homófobo. Prueba de ello son las amenazas de muerte de las que son constantemente objeto y los ciberataques que paralizan sus canales de comunicación en red: el 21 de marzo de 2013, los hackers lograron piratear la página Facebook Túnez sustituyendo el contenido feminista por versos del Corán e insultos de todo tipo. No obstante, las Femen que comparten esta conciencia del riesgo propio al activismo y una fuerte seguridad en sí mismas ${ }^{92}$, mantienen firme su objetivo de llevar a cabo acciones cada vez más radicales. Entre las más significativas figuran las manifestaciones a favor del matrimonio gay en París y contra los grupúsculos católicos integristas y de extrema derecha de Civitas; la polémica performance en la Catedral Notre-Dame tras la dimisión del papa (18 de febrero de 2013); las protestas frente a la Gran Mezquita de París donde quemaron una bandera salafista (3 abril de 2013); la perturbación del Congreso de los diputados en Madrid al grito de «Aborto es sagrado» (9 de octubre de 2013).

Pero, sin duda alguna, una de las acciones más arriesgadas se realizó en Túnez el 29 de mayo de 2013 para exigir la liberación de Amina Sboui, una militante tunecina, que había publicado una foto en Facebook con los pechos al descubierto. Algunas semanas más tarde, la joven militante fue detenida y encarcelada, lo que animó a las Femen a llevar una acción de protesta, por primera vez a pecho descubierto en un país del Magreb, lo cual les valió ser arrestadas y encarceladas. Tras un mes de detención en condiciones muy duras, la movilización internacional, el respaldo de las autoridades políticas de la Unión Europea y de los medios de comunicación lograron su liberación pero no sin levantar violentas reacciones, incluso dentro de los círculos feministas, donde se asimiló la actitud de las Femen a un tufo de neocolonialismo. A esa crítica, la líder de Femen España responde sin ambajes que «lo que algunos llaman colonialismo, nosotras lo llamamos la conciencia global de lo que son los derechos humanos ${ }^{93}$ y que el reto de las militantes de Femen «no es luchar sólo en su espacio de confort sino arriesgar el privilegio de quedarse en su país porque se sienten atravesadas por lo que ocurre fuera» ${ }^{94}$.

\footnotetext{
92 Entrevista de la autora con Lara Alcázar.

93 Ibid.

${ }^{94}$ Ibid.
} 
Sin embargo, desde 2013, esta acusación de neocolonialismo empieza a desinflarse como lo demuestra la buena acogida que recibió la acción de las Femen en un congreso cerca de París ${ }^{95}$, en septiembre de 2015, donde varios imanes integristas discutieron sobre el papel de sumisión de la mujer en el Islam. Las activistas fueron reducidas a patadas por los vigilantes de seguridad y algunos asistentes al subir a la tribuna al grito de «no pertenezco a nadie, soy mi propio profeta». En esta ocasión, la acción de las Femen fue saludada como un acto cívico por la sociedad civil y parte de la clase política francesa, quienes la interpretaron como una batalla en defensa de los derechos de las mujeres pero sobre todo en favor de la laicidad, en debate constante en Francia desde los atentados de Charlie Hebdo, el 7 de enero de 2015, y la masacre de París, el 13 de noviembre del mismo año. Esta acción, analizada a la luz del contexto global de lucha contra el terrorismo yihadista, llega a revestir otro significado y contrasta con las acusaciones de islamofobia que se abatieron contra las sextremistas desde su asentamiento en París.

Hasta el día de hoy, las militantes no han cesado de desmontar estas acusaciones reivindicando su lucha global contra todas las religiones por ser «el brazo armado de la dictadura patriarcal» ${ }^{96}$ y apelando a «la blasfemia como un derecho absoluto ${ }^{97}$. Las activistas, que se autoproclaman religiófobas y consideran que «donde la religión comienza, termina el feminismo ${ }^{98}$, rechazan tajantemente el argumento del respeto a la diferencia cultural a la hora de intervenir en un país u otro y defienden el universalismo del colectivo y su lucha por los derechos humanos en todos los rincones del planeta. En opinión de Lara Alcázar, «hay que tener en cuenta en qué país actúas, pero a mí me parece que es algo muy universal y que el hecho de hacerlo te desvincula de cualquier tipo de tradición y de vergüenza que te inculca el sistema de tu cuerpo ${ }^{99}$.

Esta defensa del universalismo, en el contexto de la lucha contra el terrorismo y el yihadismo, vuelve a poner sobre la palestra las fuertes divisiones dentro del movimiento feminista francés, en torno a dos posturas: las defensoras del feminismo de la igualdad, que reivindican la

95 Este congreso sobre la mujer musulmana se celebró el 13 de septiembre de 2015 en Cergy-Pontoise, una localidad cerca de París.

96 Manifiesto Femen, 2015, p. 50

97 Ibid.

98 Manifiesto Femen, 2015, p. 49.

99 Entrevista de la autora con Lara Alcázar. 
unidad del feminismo (la idea de un feminismo universalista, con teorías $\mathrm{y}$ valores que valen para todas las mujeres) y consideran por ejemplo el velo como un instrumento de la dominación patriarcal y religiosa; las defensoras del feminismo decolonial, que ha cobrado relevancia desde los años 2000, pretenden «descolonizar el feminismo» para construir solidaridades más allá de las diferencias culturales o religiosas, frente a las experiencias de orpresión que viven las mujeres «racializadas». En Francia, empieza a tomar cuerpo « un nuevo feminismo negro, más desacomplejado e irreverente, que se aproxima a sus raíces africanas y abunda en la problemática de la colonización y las migraciones» ${ }^{100}$.

A falta de reconocimiento en la academia, este feminismo es muy activo en las redes sociales, como lo demuestra el dinamismo del colectivo afrofeminista Mwasi, que nació en 2014, apuntando a una lucha interseccional (sexo/raza/religión/clase social/orientación sexual) y no mixta como herramienta de auto-emancipación. Una de sus fuerzas « radica en su alianza con el feminismo islámico, ambos insertos en el feminismo poscolonial, así como con el movimiento antirracista» ${ }^{101}$ : comparten el eslogan «No nos liberen, nosotras nos encargamos», e intentan dar voces a las mujeres racializadas sin depender de la agenda del feminismo mainstream. Fuertemente politizadas, las afrofeministas y las feministas musulmanas luchan contra el racismo institucional, y en particular contra la instrumentalización de las mujeres musulmanas en el contexto de la lucha anti-terrorista y antiyihadista. La polémica en torno al uso del burkini en las playas, en agosto de 2016, es reveladora del clima de crispación dentro de la sociedad francesa, pero también dentro del paisaje feminista francés, profundamente dividido.

Si las estrategias del colectivo Femen son cuestionadas por las feministas decoloniales, en particular, la desnudez como «táctica universal de protesta» ${ }^{102}$ amén de los contextos políticos, culturales y religiosos escogidos, o el riesgo de desactivación política de la protesta al exhibir los senos, percibidos socialmente como emblemas de la feminidad ${ }^{103}$, no se puede negar que ningún colectivo feminista logró adquirir hasta ahora un

100 «Afrofeministas, sabemos emanciparnos solas», Pikara Magazine, 6 de octubre de 2016. <http://www.pikaramagazine.com/2016/10/afrofeministas-sabemos-emanciparnossolas/>. [6/12/2016]

101 Ibid.

102 Manifiesto Femen, 2015, p. 16.

103 Méndez Pérez, 2014, p. 27. 
eco mediático tan amplio y las problemáticas feministas tanta visibilidad fuera de los círculos feministas. Como explica Lara Alcázar, lo que anima a las Femen es que «el mensaje llegue a todo el mundo porque muchas veces el feminismo sólo se dirige a otras feministas y lo que tenemos que intentar hacer es sacar el tema del gueto e intentar introducirlo como un eje transversal dentro de la sociedad» ${ }^{104}$.

Ahora bien, lo que llama la atención es que el impacto mediático de Femen no se corresponde con un incremento significativo de las afiliaciones, aunque «lo más importante es ser más, siempre más y seguir haciendo acciones, estar presentes cada vez más dentro del tejido político» ${ }^{105}$. A pesar de estas perspectivas, las secciones siguen siendo de tamaño pequeño, entre diez y veinte activistas, a excepción de la sede parisina que logró reunir unas cuarenta activistas, pero la ideología radical de Femen y sus praxis centradas en el enfrentamiento cara a cara no están exentas de riesgos y excluyen de hecho a numerosas mujeres, que bien no se sienten identificadas, bien no son aptas, mental y/o físicamente, para llevar semejante combate. Si el movimiento Femen se ha granjeado la simpatía y, hasta la protección de los medios de comunicación, en la práctica estas amazonas no logran dar pie a un movimiento feminista masivo. Paradójicamente, a pesar de su enorme visibilidad internacional, las militantes Femen representan una minoría pero, es justo reconocerlo, un comando perfectamente estructurado y disciplinado en torno a una líder carismática, Inna Shevchenko, dispuesta a liderar una nueva «revolución feminista» de calado internacional y que, en palabras de Lara Alcázar, es «como una chispa que vino del grupo primario y que ha sabido hacer que todas nos sintamos parte de esto» ${ }^{106}$.

Es cierto que la trayectoria del colectivo, sus repertorios de acción, sus estrategias para rejuvenecer la imagen del feminismo, su cuestionamiento en torno a la recuperación del cuerpo como herramienta de resistencia, la voluntad de crear una «Internacional feminista» ${ }^{107}$ que comparta una misma identidad y una acción colectiva más allá de las fronteras, nos obligan a cuestionarnos sobre la renovación de las prácticas feministas contemporáneas, sobre el relevo generacional del movimiento feminista, sobre su dimensión a la vez micro y macro, e incluso sobre la emergencia

\footnotetext{
104 Entrevista de la autora con Lara Alcázar.

105 Ibid.

106 Entrevista de la autora con Lara Alcázar.

107 Ibid.
} 
de una cuarta ola de activismo feminista radical cuyos modos de acción se articulan mediante un ir y venir incesante entre el activismo on line y el activismo off line, en la calle, visible, insolente y subversivo.

\section{Conclusión}

El examen de las acciones y teorías promovidas por los colectivos feministas que se consolidaron en la década de los años 2000 sugiere varias reflexiones que confirman la gran heterogeneidad del activismo feminista joven, tanto en sus formas de acción como en sus planteamientos teóricos. Este polimorfismo confirma también un relevo generacional y una actualización de las temáticas clásicas del feminismo en el espacio militante francés. Si bien es cierto que en nuestro estudio hemos dejado de lado los «nuevos feminismos», y en particular las corrientes queer y transfeminista, que vienen a renovar las teorías clásicas del feminismo ${ }^{108}$, podemos hablar de mutación del feminismo dentro de la continuidad y de unos feminismos en movimientos y en tránsito ${ }^{109}$. Dicho de otro modo, estos colectivos, si bien reclaman nuevas formas de actuación y, en particular el uso de las nuevas tecnologías como arma de resistencia, no evidencian una ruptura total con respecto a lo anterior. Como se ha mencionado, muchas de estas prácticas entrelazan viejas y nuevas problemáticas y son herederas de la acción colectiva feminista, entendida como «las acciones llevadas a cabo por colectivos de mujeres cuya unión es el resultado de un proceso continuo de renegociación de unas identidades comunes» ${ }^{110}$. En el contexto actual, el reto es observar cómo mutan los discursos y las prácticas feministas, partiendo del postulado de que nunca ha existido un feminismo único. Si el feminismo es, como lo definía Françoise Collin, «una revolución permanente (...) que se piensa y se inventa a cada paso» ${ }^{111}$, le corresponde a cada generación imprimir su estilo, imaginando, repensando, transformando, construyendo o inventando nuevos desafíos y prácticas de resistencia para construir un nuevo modo del hacer político.

108 Véase Bergès, 2015.

109 Nos referimos aquí al título del artículo de Méndez Pérez, 2014, p. 27: «Del corsé a los pechos desnudos, de las sufragistas a las FEMEN, de las «otras feministas» a las institucionales, de las «queer» a las «transfeministas», es ya larga la cadena de generaciones de feministas en movimiento».

${ }^{110}$ Del Moral, 2016, p. 20.

111 Collin, Kaufer, 2005, p. 17. 


\section{Bibliografía}

BAILlARgEOn, Mercédès et collectif les Déferlantes (dir.), Remous, ressacs et dérivations autour de la troisième vague, Les éditions du remue-ménage, Québec, 2011.

BARD, Christine (dir.), Les féministes de la deuxième vague, Rennes, PUR, 2012.

$\mathrm{BARD}$, Le féminisme au-delà des idées reçues, Le Cavalier bleu, Paris, 2012

BERGÈs, Karine, «Quand les féminismes s'indignent : le mouvement du 15-M entre revendications égalitaires et reproductions des logiques patriarcales», FISBACH, Erich; RABATÉ, Philippe, HispanismeS, n 4, juillet 2014. <http://www. hispanistes.org>. [10/12/2016].

BERGÈs, Karine, «Sexualités dissidentes et performance transféministe : le pornoterrorisme de Diana J. Torres», PRAT, Isabelle; TERRASA, Jacques (éd.), Image \& création au féminin, Editions Hispaniques, 2015, pp. 37-55.

BERGÈs, Karine, «Quand le féminisme s'exhibe : l'exemple du collectif Femen», Résistantes, militantes, citoyennes. L'engagement politique des femmes aux $X X^{e}$ et $X X I^{e}$ siècles, BERGÈs, Karine «et al»(dir.), Rennes, PUR, collection «Mondes hispanophones », $\mathrm{n}^{\circ} 43,2015$, pp. 233-245.

BLAIs, Mélissa «et al», «Pour éviter de se noyer dans la (troisième) vague : réflexions sur l'histoire et l'actualité du féminisme radical», Recherches Féministes, 2007, vol. 20, $\mathrm{n}^{\circ} 2$. <http://id.erudit.org/iderudit/017609ar>. [05/09/2016].

BOURCIER, Marie-Hélène/Sam ; MoLINIER, Alice, Comprendre le féminisme, Max Milo, Paris, 2012.

BUTLER, Judith, «Cuerpos en alianza y la política de la calle», Revista Trasversales, junio 2012, n 26. <http://www.trasversales.net/t26jb.htm>. [13/12/2016]

CACACE, Marina, Mujeres y Jóvenes. Valores cultura y comportamiento frente a frente, Narcea Ediciones, Madrid, 2006.

Сово, Rosa, «Globalización y nuevas servidumbres de las mujeres», Amorós, Celia; De Miguel, Ana (ed.), Teoría feminista: de la Ilustración a la globalización. De los debates sobre el género al multiculturalismo, Minerva Ediciones, Madrid, 2005, tomo 3, pp. 265-300.

Collin, Françoise, Kaufer, Irène, Parcours féministe, Editions Labor, Paris, 2005.

Del Moral VArgas, Marta, «Protestas transgresoras, acciones revolucionarias. Campañas por el derecho al voto e las mujeres (1918-1924)», BRANCIFORTE, Laura; ORSI, Rocío, La guillotina del poder. Género y acción socio-política, Plaza y Valdés, Madrid, 2015, pp. 19-44.

Dorlin, Elsa; BESsin, Marc, «Les renouvellements générationnels du féminisme : mais pour quel sujet politique ?», Féminismes. Théories, mouvements, conflits, Théories, mouvements, conflits. L'homme et la société. Revue internationale et de synthèse en sciences sociales, L'Harmattan, Paris, 2005. 
Dumont, Michèle, «Réfléchir au féminisme du troisième millénaire», Dialogues sur la troisième vague féministe, NENGEH MENSAH, Maria (coord.), Les éditions du remue-ménage, Québec, 2005, pp. 59-73.

FALUDI, Susan, Reacción : La guerra no declarada contra la mujer moderna, Anagrama, Madrid, 1993.

FASSIN, Eric, «Trouble-genre», Trouble dans le genre: pour un féminisme de la subversion, Editions Amsterdam, Paris, 2015.

Femen, ACKerman, Galia (trad.), Calmann-Levy, Paris, 2013.

FInDLEn, Barbara, (dir.), Listen up: Voices from the Next Feminist Generation, SealPress, Seattle, 1995.

FOUREST, Caroline, Inna. Les paradoxes d'une Femen, Grasset, Paris, 2014.

GIL, Silvia, Nuevos feminismos. Sentidos communes en la dispersión, Traficantes de Sueños, Madrid, 2011.

Lamoureux, Diane, Les possibles du féminisme. Agir sans «nous », Les éditions du remue-ménage, Québec, 2016.

Manifiesto Femen, ArAgón, Irene (trad.), Hoja de Lata Editorial, Asturias, 2015.

MARSILI, Marta «Les blogs féministes : un «genre autre» de communication. Le cas italien», Lootvoet, Valérie (dir.), Femmes et Médias, Médias et femmes, Université des femmes, Bruxelles, 2010,

MARTÍNEZ GonZÁLEZ, María, Identidades feministas en proceso. Reiteraciones y activaciones emocionales en las movilizaciones feministas del Estado español, Tesis doctoral, Universidad del País Vasco, 2015.

MÉNDEZ PÉREZ, Lourdes, «Feminismos en movimiento en el Estado español: ¿reampliando el espacio de lo político?», Revista andaluza de antropología, Los movimientos globales y la contestación al orden global, 2014, n. 6. $<$ http://www.revistaandaluzadeantropologia.org/index.php?page=mendezlourdes $>$. [10/12/2016]

Nengeh Mensah, Maria, «Une troisième vague féministe au Québec», Dialogues sur la troisième vague féministe, NENGEH MENSAH, Maria (coord.), Les éditions du remue-ménage, Québec, 2005, pp. 11-30.

OfFEN, Karen, «Defining Feminism : A comparative Historical Approach»», Signs, 1998, n 1, pp. 119-157, citado en Le siècle des Féminismes, Gubin, Eliane «et al» (dir.), Les éditions de l'Atelier, Paris, 2004.

OPREA, Denise-Adriana, «Du féminisme (de la troisième vague) et du postmoderne», Recherches féministes, 2008, vol. 21, n 2, pp. 5-28. <https://www. erudit.org/revue/rf/2008/v21/n2/029439ar.html>. [10/12/2016].

PAGE, Geneviève, «Variations sur une vague», Dialogues sur la troisième vague féministe, Nengeh Mensah, Maria (coord.), Les éditions du remue-ménage, Québec, 2005, pp. 42-48.

PANKHURST, Emmeline, Sufragette. My own story, Hesperus, London, 2015.

PAVEAU, Marie-Anne, «La petite vertu discursive des Femen», La Pensée $d u$ discours, 3 de marzo de 2013. <http://penseedudiscours.hypotheses. org/11603?utm_source=aler $>$. [24/10/2016]. 
PICQ, Françoise, «El hermoso pos-mayo de las mujeres», Dossiers Feministes, «Mayo del 68: revolución y género», 2008, $\mathrm{n}^{\circ}$ 12, pp. 69-76. <http://www. raco.cat/index.php/DossiersFeministes/article/viewFile/140707/191949>. [10/12/2016].

PICQ, Françoise Libération des femmes, quarante ans de mouvement, éditionsdialogues.fr, Brest, 2010.

Riot-SARCEy, Michèle, Histoire du féminisme, La découverte, Paris, 2002.

TARAUD, Christelle, Les féminismes en question. Éléments pour une cartographie, Editions, Paris, Amsterdam, 2005

TriLla, Jaume (Coord.), Jóvenes y espacios públicos, Ed. Bellaterra, Madrid, 2011.

VAlCÁrcel, Amelia, «Qué es y qué retos plantea el feminismo», Hacia la plena ciudadanía de las mujeres, abril 2004, Urbal red12mujerciudad, Barcelona, <http://docplayer.es/4392551-Que-es-y-que-retos-plantea-el-feminismo. html>. [10/12/2016].

ZAFRA, Remedios, Un cuarto propio conectado, Fórcola, Madrid, 2010.

WajCMAn, Judy, El Tecnofeminismo, Cátedra, Madrid, 2006.

WALKER, Rebecca (dir.), To be Read: Telling the Truth and Changing the Face of Feminism, Anchor Books/Doubleday, New York, 1995.

\section{Financiación}

Esta investigación se enmarca en el proyecto de investigación «Género, compromiso y transgresión, 1890-2016» (FEM2016-76675-P), concedido por el Ministerio de Economía, Industria y Competitividad.

\section{Datos de la autora}

Karine Bergès (karine.berges@u-cergy.fr) es profesora titular de Historia contemporánea española en la Universidad de Cergy-Pontoise (París, Francia), miembro del centro de investigación AGORA, responsable de la Unidad de Igualdad entre hombres y mujeres en esta misma universidad. Su labor de investigación se centra principalmente en la historia de las mujeres bajo el franquismo y, más recientemente, sobre los feminismos radicales y autónomos madrileños de los años ochenta hasta la época actual. Publicación: Résistantes, militantes, citoyennes. $L^{\prime}$ engagement politique des femmes au $X X^{e}$ et $X X{ }^{\circ}$ siècles, Karine Bergès, Mercedes Yusta, Diana Burgos et Nathalie Ludec (coord.), Paris, PUR, 2015. 